\title{
PENGAMPUNAN DAN PERJANJIAN DALAM PEMIKIRAN HANNAH ARENDT
}

\author{
Jadi S. Lima \\ Sekolah Tinggi Teologi Reformed Injili Internasional
}

\begin{abstract}
ABSTRAK: Menurut Hannah Arendt, kapasitas manusia untuk mengampuni kesalahan, membuat perjanjian, dan menepati janjinya, dapat menjadi solusi yang lebih baik bagi predicament bawaan dari aktivitas bertindak, daripada solusi yang lebih sering dijumpai, yaitu kontrol. Kontrol telah menjadi solusi umum dalam sejarah filsafat politik Barat sejak Plato bagi ketiga predicament tindakan, yakni: unpredictability, irreversibility, dan inability to locate the subject of action. Arendt menelusuri sejarah solusi ini di dalam penggunaan metaforametafora proses fabrikasi yang dikenakan kepada proses-proses politik. Ini adalah substitusi berbahaya yang telah memimpin kepada penindasan, alienasi, dan kekerasan di dalam sejarah politik. Arendt berargumen bahwa pengampunan dan perjanjian, dua kapasitas manusia yang menimbulkan iman dan pengharapan adalah jalan keluar yang lebih baik daripada penggunaan kekerasan dan kontrol di dalam urusan politik. Artikel ini akan menelusuri sumber-sumber Yudaisme dan Kristen di dalam usulan Arendt ini. Pada akhir artikel ada apropriasi usulan Arendt ini untuk memahami dinamika politik di Indonesia.
\end{abstract}


KATA KUNCI: revolusi, pengampunan, rekonsiliasi, perjanjian, bekerja, karya, keadilan, pengharapan, Yesus.

ABSTRACT: According to Hannah Arendt, human capacity to forgive and to make and keep a promise, can be a better solution for the inherent predicament of action than the more popular paradigm of control. Platonic cure for the triple predicament of action is to substitute 'making for acting'. This dangerous substitution can be traced in the use of metaphors originated in the process of fabrication in the political arena. This leads to alienation, oppression, domination, violence in the course of Western history. The pluralities and equalities of voices indeed lead to uncertainty of the future, hence a lost sense of control, but Arendt believes the power inherent in the human capacity to make promises and to forgive as a better option than substituting 'making for acting'. This article will retrace the Judeo-Christian roots of Arendt's thought, evaluate her use of the sources, and appropriate her insights to get a better understanding of the political situation in Indonesia.

KEYWORDS: revolution, forgiveness, reconciliation, promise, labor, work, action, justice, hope, Jesus.

\section{Pengantar}

Bruce Wayne: What if I do Rachel? My parents deserved justice.

Rachel Dawes: You're not talking about justice. You're talking about 
revenge.

Bruce Wayne: Sometimes they're the same.

Rachel Dawes: No, they're never the same, Bruce. Justice is about harmony. Revenge is about you making yourself feel better. Which is why we have an impartial system.

Bruce Wayne: Your system is broken.

- Batman Begins (2005)

Ketidakadilan dan kejahatan adalah fakta yang tidak dapat dilepaskan dari jalannya sejarah. Rasa keadilan dilukai, kepercayaan dikhianati, dan segera saja kepercayaan satu sama lain, salah satu social capital yang paling penting, akan terkikis seiring dengan semakin lamanya kita hidup dan melihat realitas. Bagaimanakah kita menjawab permasalahan ini? Penulis kira jelas bagi sebagian besar orang bahwa jawabannya bukanlah pada pembalasan dendam. Tetapi jika bukan pembalasan, bagaimanakah keadilan dan harmoni dapat dipulihkan? Samar-samar kita mengerti bahwa jawabannya ada di dalam hal-hal semacam niat baik, pengampunan, cinta kasih, ketulusan, perjanjian yang diapat diandalkan, dan kepercayaan yang dipulihkan. Tetapi walaupun hal-hal ini banyak dijumpai di dalam kesalehan pribadi, pengalaman keagamaan, ataupun kehidupan komunal antar saudara seiman, tetapi penghayatannya di dalam ruang publik, apalagi dalam konteks dunia yang pluralistik ini, tentu

1 Dialog ditulis oleh Christopher Nolan dan David S. Goyer berdasarkan karakter-karakter yang dibuat oleh Bob Kane. Sumber:

http://www.imdb.com/title/tt0372784/fullcredits?ref_=tt_ov_wr\#writers diakses pada 19

September 2014. 
saja memerlukan penerjemahan.

Pengampunan adalah topik yang banyak kita dapati di dalam diskusi seputar Kekristenan dan Alkitab. Sebagaimana datangnya Kerajaan Allah sebagai esensi dari berita Injil Yesus Kristus memiliki cakupan seluas ciptaan dan daya transformasi seradikal perubahan hati manusia dan arah tiap-tiap aspek ciptaan yang dikelolanya, tema pengampunan ini tentu saja harus juga mengarahkan cara-cara kita berada di dalam dunia publik ('sekuler'). ${ }^{2}$ Pengampunan ada di dalam jantung Kekristenan itu sendiri: orang-orang Kristen percaya bahwa di dalam Yesus dari Nazaret, khususnya di dalam peristiwa penyaliban, kematian, dan kebangkitan-Nya, Allah Abraham telah mengampuni dan 'membenarkan' orang-orang yang percaya kepada berita Injil Yesus itu. Umat Israel yang baru, yang dibangkitkan oleh Roh Allah dari segala bangsa untuk percaya kepada datangnya Kerajaan Allah di dalam pemberitaan Kabar Baik adalah orang-orang yang diampuni dosanya oleh Sang Pencipta. Dalam doa yang diajarkan oleh Tuhan Yesus kita juga melihat sentralnya tema

2 Istilah 'sekuler' di sini tidak mencerminkan bahwa penulis menerima dikotomi hidup manusia ke dalam dua ranah yang tidak saling berkaitan antara 'sekuler' dan 'sakral' seperti yang kita jumpai di dalam pandangan dunia Kekristenan Eropa Barat pada Abad Pertengahan. Penulis berkomitmen dan berangkat dari pandangan dunia 'creational monism', yang percaya bahwa Allah sesungguhnya menciptakan satu saja dunia yang baik (tetapi telah jatuh ke dalam dosa) sehingga segala sektor dalam hidup manusia adalah diciptakan oleh Allah Abraham secara sempurna dan baik, di dalam segala diversitasnya. Secara ontis tidak ada sektor kehidupan yang lebih dekat ataupun jauh dari Allah. Dengan demikian penulis menolak dikotomi ontologis antara 'sakral' dan 'sekuler' itu dan hanya memakai istilah 'sekuler' untuk mengakomodir pemakaian istilah yang dipakai oleh Hannah Arendt di dalam buku The Human Condition, 2nd ed. (Chicago: University of Chicago Press, 1958) yang dibahas di dalam artikel ini. 
pengampunan ini. ${ }^{3}$ Kita diajarkan untuk meminta pengampunan kepada Bapa sebagaimana kita juga mengampuni orang yang bersalah kepada kita. Jadi di sini bukan hanya dimensi vertikal yang terlibat, pelanggaran yang kita lakukan kepada hukum Allah dan pengampunan yang kita terima dari Dia, tetapi juga ada dimensi horizontal yang melekat dalam doa sehubungan dengan datangnya Kerajaan Surga itu, yaitu terjadinya saling mengampuni di antara anak-anak Bapa itu sendiri, ataupun di dalam pergumulan umat Tuhan dalam menghidupi pengampunan sebagai solusi bagi dosa dan pelanggaran di dalam ranah publik. Misalnya saja, kita dapat menyebutkan peranan Desmond Tutu dan umat Kristiani di Afrika Selatan di dalam rekonsiliasi nasional yang mereka lakukan di dalam era post-apartheid, ataupun apa yang dilakukan orang-orang Kristen mula-mula terhadap para penganiayanya di dalam Abad Pertama.

Perjanjian dan prinsip bertindak berdasarkan perjanjian yang telah disepakati sebelumnya, adalah salah satu pondasi paling mendasar di dalam tatanan dunia modern. ${ }^{4}$ Hukum dan perjanjian internasional memungkinkan umat manusia selama berabad-abad untuk bekerja sama, hidup bersama dan menyelesaikan konflik tanpa kekerasan. Dapat dikatakan dunia seperti yang kita kenal hari ini

3 Matius 6: 12 yang berbunyi: “... dan ampunilah kami akan kesalahan kami, seperti kami juga mengampuni orang yang bersalah kepada kami ...” (LAI, TB 1974)

4 Prinsip pacta sunt servanda (kesepakatan harus ditepati) yang dapat ditelusuri asalmuasalnya setua sistem hukum Romawi, adalah salah satu prinsip paling mendasar di dalam hukum internasional. Untuk studi yang mendalam mengenai prinsip ini dapat dilihat dalam Josef L. Kune, "The Meaning and the Range of the Norm Pacta Sunt Servanda" dalam The American Journal of International Law, Vol. 39, Nr. 2, April 1945. 
tidak akan pernah ada tanpa adanya perkembangan dalam formalisasi perjanjian dan konstitusi. Umat Kristiani dan juga Yudaisme memandang perjanjian sebagai sesuatu yang sangat sentral di dalam kehidupannya. Allah Abraham, Ishak dan Yakub yang juga adalah Allahnya umat Kristiani adalah Allah yang berjanji kepada manusia. Iman Kristen itu sendiri memandang Yesus Kristus sebagai penggenapan dari janji Allah Abraham yang telah dinantikan baik oleh umat Israel maupun oleh 'segala mahluk' selama berabad-abad. Demikian, perjanjian dan pengampunan adalah dua topik yang sangat sentral di dalam baik Kekristenan maupun Yudaisme. Kedua topik ini juga begitu relevan dengan dunia kita hari ini secara umum, sehingga penulis merasa perlu untuk meninjau kembali kedua topik ini, khususnya di dalam tahun pemilu 2014 dimana sebagai bangsa, Indonesia sedang menghadapi titik balik yang penting, baik di dalam suksesi kekuasaan, kontinuasi dari gerakan reformasi yang telah dimulai tahun 1998, maupun 'revolusi mental' yang telah sangat mendesak untuk segera dimulai mengingat telah sekian lama Republik ini dikenal luas di dunia sebagai salah satu bangsa dengan tingkat korupsi paling tinggi. ${ }^{5}$ Peralihan kekuasaan dan perubahan seringkali dihantui oleh kekerasan dan ketidakadilan, sebagaimana kita alami di dalam tragedi Mei 1998 dan 1965-66. Sebagaimana dikatakan Marx bahwa: "kekerasan adalah bidan yang menolong persalinan masyarakat tua yang sedang mengandung masyarakat

5 Indonesia menempati ranking 114 dari 177 negara dengan skor 32 dari 100. Versi Transparency International, http://www.transparency.org/country\#IDN diakses pada 19 September 2014. 
muda" - demikian kita menyaksikan lahirnya masyarakat yang baru seringkali tidak dapat dipisahkan dari penggunaan kekerasan. ${ }^{6}$ Tentu saja kita tidak menghendakinya karena seperti dikatakan Martin Luther, "Tidak ada yang baik dapat dihasilkan dari kekerasan." Dengan demikian penulis kira usulan dari Arendt mengenai peranan perjanjian dan pengampunan dalam kancah politik perlu dipertimbangkan dengan serius sebagai sesuatu usulan yang relevan hari ini.

Hannah Arendt, seorang filsuf berdarah Yahudi Jerman yang karya-karyanya banyak diwarnai dengan pengaruh Judeo-Christian dan juga tradisi filsafat idealisme dan eksistensialisme Jerman, menuliskan ide-ide yang kreatif dan brillian mengenai pengampunan dan perjanjian sebagai jalan keluar dari apa yang dipahaminya sebagai kesulitan-kesulitan (predicaments) di dalam keadaan kita sebagai manusia, khususnya sebagai mahluk yang dapat dan memiliki potensi untuk bertindak serta berkata-kata, sebagai perwujudan individualitas manusia yang plural. Dalam pembahasannya Arendt menyebutkan Yesus dari Nazaret sebagai seorang 'penemu' dari kekuatan pengampunan, sementara Abraham orang Ur disebutnya sebagai orang penemu dari kekuatan perjanjian. ${ }^{7}$ Disamping analisanya yang kreatif dan mendalam, komentar Arendt mengenai peranan Yesus dan Abraham inilah yang

\footnotetext{
6 Karl Marx, Leon Trotsky, ed., The Essential Marx (New York: Dover, 1939, 2006$) 33$.

7 Hannah Arendt, The Human Condition, 2nd ed. (Chicago: University of Chicago Press, 1958), 239 dan 243.
} 
menghantar penulis untuk menganalisa usulannya dari titik berangkat Kekristenan.

\section{Pengampunan dan Perjanjian}

Analisa mengenai pandangan Arendt tentang pengampunan dan perjanjian di dalam artikel ini akan terutama diambil dari karyanya yang berjudul The Human Condition (Chicago: University of Chicago Press, 1958), khususnya dalam bab ke lima di mana Arendt memaparkan pengamatannya mengenai tindakan (action). ${ }^{8}$ Sebelum membahas pandangan Arendt mengenai pengampunan dan perjanjian, penulis akan terlebih dahulu memaparkan konteks pembahasannya dalam buku ini. Arendt membahas pengampunan sebagai salah satu bagian dari analisanya atas tindakan manusia. Di dalam sistematika penjelasannya atas eksistensi manusia, Arendt membedakan aktivitas manusia ke dalam tiga bagian: jerih lelah (labor), karya (work) dan tindakan (action). Distingsi yang dibuat Arendt atas ketiga jenis aktivitas manusia berfungsi untuk menjelaskan bagaimana aktivitas manusia berhubungan dengan identitasnya, dan bagaimana tiap-tiap individu eksis dan menyadari (serta disadari) eksistensinya di dalam jejaring keseluruhan kemanusiaan dalam sejarah. Buku The Human Condition ini sendiri disebut oleh Arendt dalam proposal riset yang dikirimnya ke yayasan Rockefeller sebagai suatu prolegomena bagi karya yang lebih

$8 \quad$ Ibid., $175-247$. 
sistematis dalam Teori Politik. ${ }^{9}$ Dalam analisanya, Arendt menekan kapasitas manusia untuk memulai sesuatu yang baru, yang belum pernah ada sebagai bagian yang tidak terlepaskan dari karakteristik manusia maupun tiap-tiap individu sebagai mahluk yang unik. ${ }^{10} \mathrm{Di}$ dalam kapasitas untuk memulai sesuatu yang sungguh-sungguh baru di dalam tindakan itulah terletak keunikan manusia dan tiap individu. ${ }^{11}$ Menurut Arendt, kapasitas untuk menghasilkan sesuatu yang baru itu mewujud di dalam aktivitas manusia, di dalam mengadanya kita di hadapan manusia-manusia lain melalui tindakan dan ujaran-ujaran yang mengungkapkan 'siapakah kita' (who are you) secara distingtif dari 'apakah kita ini' (what are you). ${ }^{12}$ Dalam analisanya mengenai sejarah politik dan teori politik Barat, Arendt menelusuri banyak buah-buah buruk muncul di dalam sejarah Barat dari sikap melarikan diri dari tanggungjawab untuk bertindak ini ke dalam substitusi yang telah dapat ditemukan di dalam teori politik

$9 \quad$ Ibid.,ix.

10 Margaret Canovan, di dalam kata pengantar untuk edisi kedua The Human Condition (1998) menyebut Hannah Arendt sebagai seorang Teoretisi Permulaan (Theorist of Beginnings). Ibid., vii.

11 Ia mengatakan, "Action alone is the exclusive prerogative of man; neither a beast nor a god is capable of it." Ibid., 22-23.

12 Jika jawaban atas pertanyaan 'what are you' merujuk kepada kebersamaan dan persamaan kita dengan manusia-manusia lain di dalam satu spesies, golongan ataupun tipe tertentu, maka rujukan dari 'who are you' selalu bersifat individual dan unik. Hanya ada rujukan tunggal bagi 'who are you' yaitu pribadi unik yang bersangkutan. Si subyek itu sendiri di dalam pluralitasnya. Arendt menjelaskan hubungan kelahiran (natalitas) dengan tindakan dan ujaran (speech) dengan munculnya keunikan tiap subyek, sebagai berikut: "If action as beginning corresponds to the fact of birth, if it is the actualization of the human condition of natality, then speech corresponds to the fact of distinctness and is the actualization of the human condition of plurality, that is, of living as a distinct and unique being among equals." Ibid., 175-176, dan 178. 
Plato, yaitu dengan menggantikan tindakan dengan karya. ${ }^{13}$ Pelarian ini, dalam analisa Arendt, telah mengakibatkan hilangnya kebebasan dan pluralitas di ruang publik serta saratnya kekerasan dan penindasan dalam sejarah. Tetapi, pelarian ini diperlukan karena orang tidak menemukan pemecahan yang lain bagi berbagai predicament yang terkandung di dalam tindakan dan kata-kata manusia, yaitu ketidaktentuan dampak dari tindakan dan kata-kata serta ketidakterulangannya (unpredictability dan irreversibility). Menurut Arendt substitusi yang berbahaya ini tidaklah diperlukan jika kita dapat menanggulangi berbagai predicament tersebut melalui kemampuan manusia untuk berjanji dan menepati janji serta mengampuni kesalahan orang lain.

\section{Konteks}

\section{Tiga Aktivitas Manusia: Jerih Lelah, Karya, dan Tindakan}

Dalam analisa fenomenologisnya, Hannah Arendt membedakan antara tiga macam aktivitas manusia: jerih lelah (labor), karya (work) dan tindakan (action). Jerih lelah berhubungan dengan kehidupan manusia sebagai mahluk biologis-hewani, yaitu dalam rangka bertahan hidup dan meneruskan keturunan, karya berhubungan dengan kehidupan manusia yang menghasilkan artefak-artefak kebudayaan dalam rupa bangunan-bangunan dan karya-karya seni maupun teknologi, sedangkan tindakan berkaitan

13 Ibid., 220-230. 
dengan pluralitas tiap individu yang distingtif. ${ }^{14}$ Jerih lelah menempati tingkatan terendah di dalam cara manusia mengada. Manusia memerlukan buah dari jerih lelah ini, semisal makanan, pakaian, rumah, dan beresnya urusan-urusan tata rumah tangga, akan tetapi ini semua tidak membuat keberadaan kita dikenang lama setelah kita mati. Inilah sebabnya orang-orang Yunani yang ingin melampaui mortalitasnya menghindari pekerjaan jerih lelah. ${ }^{15}$ Mereka menganggap 'kesibukan sehari-hari yang tak meninggalkan jejak' ini sebagai suatu kutukan yang daripadanya mereka ingin dilepaskan. ${ }^{16}$ Mereka melimpahkannya kepada para budak yang akan mengerjakannnya bagi mereka. Jerih lelah para budak dengan tubuhnya tidak menghasilkan apapun yang patut untuk dikenang walaupun melalui kerja mereka para tuan dapat membebaskan diri dari kesia-siaan jerih lelah ini untuk melakukan aktivitas yang lebih menjamin imortalitas mereka (menghasilkan suatu 'nama' yang dikenang) - mungkin melalui keterlibatan mereka di dalam tindakan

\footnotetext{
14 Ibid., 7.

15 Arendt membedakan antara 'imortalitas' yang ingin digapai oleh masyarakat Yunani kuno dengan 'kekekalan' yang ada dalam konsep agama-agama Asia. Dewa-dewa Yunani dan alam semesta tidaklah bersifat kekal dalam pengertian bebas dari waktu, imortal semata berarti 'endurance in time'. Para dewa bersifat imortal karena mereka tetaplah ada di alam semesta yang bersifat siklik ini, bahkan hewan-hewanpun imortal dalam pengertian ini karena mereka sebagai spesies dimengerti sebagai abadi. Manusialah satu-satunya keberadaan yang bersifat 'mortal' karena sebagai individu mereka akan lenyap. Mungkin di sini kita lebih tepat menyebut imortalitas sebagai 'keabadian' daripada 'kekekalan'. Abadi itu berarti 'bertahan berabad-abad' sementara 'kekal' berarti berada di luar waktu. Ibid., 17-18.
}

16 Arendt menulis bahwa di dalam masyarakat Yunani kuno: "Contempt for laboring, originally arising out of a passionate striving for freedom from necessity and no less passionate impatience with every effort that left no trace, no monument, no great work worthy of rememberance ..." Ibid.,81. 
politik pada sebuah politeia. Jerih lelah adalah sisi eksistensi manusia sebagai hewan pekerja, animal laborans yang rendah dan tidak berarti. ${ }^{17}$ Tidak demikian dengan karya. Karya adalah modus mengadanya manusia sebagai homo faber yang beraktivitas untuk menambahkan suatu obyek buatan tangannya, yang tidak pernah ada sebelumnya, ke dalam dunia. Melalui karyanya, manusia membentuk sebuah 'reifikasi' - suatu 'bangunan' kebudayaan atau teknologi, misalnya: lukisan-lukisan, patung-patung, karya arsitektur, ataupun penemuan-penemuan teknologi yang membuat si perancang atau pembuat tetap dikenang sebagai seseorang yang menghasilkan karya itu. Ini adalah cara yang lebih baik untuk mencapai imortalitas. Artefak baru yang kita tambahkan ke dalam dunia untuk mewujudkan kepenguasaan kita atasnya, akan membuat orang-orang yang menghasilkannya dikenang setidaknya sepanjang artefak itu tidak dihancurkan. ${ }^{18}$

Buah dari jerih lelah memenuhkan syarat minimal untuk kita bertahan hidup, dan buah dari karya membuat kita dikenang orang selama karya tersebut bertahan, tetapi orang tetap dapat eksis sebagai manusia tanpa melakukan sendiri kedua jenis aktivitas tersebut. Orang dapat melimpahkan keharusan untuk berjerih-lelah kepada para budak, dan orang tidak usah menambahkan artefak baru apapun ke dalam dunia ini, ${ }^{19}$ dan tetap dapat disebut sebagai

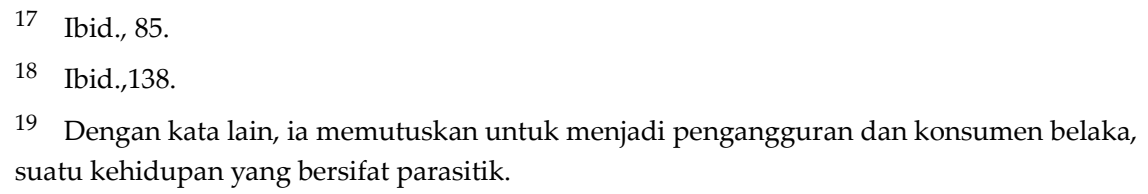


manusia seutuhnya. ${ }^{20}$ Tetapi manusia tidak dapat eksis sebagai manusia, ataupun terlibat di dalam 'dunia orang-orang hidup,' terlepas dari tindakan. Tanpa tindakan, manusia kehilangan keunikannya sebagai individu yang tak tergantikan. Pluralitas tiap manusia, bagi Arendt, adalah persyaratan dasar bagi tindakan dan perkataan (action and speech). Pluralitas unik tiap individu mengandung karakter ganda, yaitu: persamaan (equality) dan distingsi (distinction). ${ }^{21}$ Tanpa distingsi (baik distingsi antar individu ataupun distingsi intra individu - dimana orang berbeda dari dirinya di masa lampau, masa kini dan masa depan) orang tidak akan memerlukan perkataan ataupun tindakan untuk membuat dirinya dimengerti, karena ia akan selalu telah dimengerti. ${ }^{22}$ Dalam keadaan ini kebutuhan dan keinginan secara langsung, tanpa mediasi, telah cukup. Sedangkan tanpa persamaan orang tidak akan pernah dapat memahami ataupun mengantisipasi kebutuhan orang-orang lain sehingga tindakan dan perkataan juga tidak diperlukan. ${ }^{23}$ Jadi, tindakan dan perkataan dimungkinkan oleh adanya pluralitas tiap individu yang unik dan sekaligus menyingkapkan pluralitas itu kepada dunia. ${ }^{24}$ Di dalam tindakan dan perkataan manusia menyingkapkan di hadapan dunia dan orang-orang lain akan

\footnotetext{
20 "The life of an exploiter or slaveholder and the life of a parasite maybe unjust, but they certainly are human." Ibid., 176.

21 Ibid.

22 Ibid.,176.

23 Ibid.,175.

24 Ibid.,180.
} 
siapakah dirinya. ${ }^{25}$ Sebuah kehidupan tanpa tindakan dan perkataan adalah sebuah 'kematian terhadap dunia' - orang yang menghidupi kehidupan semacam ini telah berhenti menjadi manusia karena ia tidak lagi hidup di tengah manusia. ${ }^{26}$ Bayangkan orang yang diisolasi di dalam sebuah ruang tahanan tanpa boleh melakukan apapun ataupun mengutarakan apapun secara berarti kepada siapapun. Walaupun ia masih bernapas dan belum mengalami mati otak, tetapi ia dapat dikatakan telah mati menurut penjelasan Arendt ini. ${ }^{27}$ Ia berhenti eksis. Jelas di sini bagaimana peranan penting tindakan (dan perkataan) di dalam pemikiran Arendt. Keduanya adalah syarat mutlak bagi keberadaan suatu individu sebagai pribadi unik yang eksis. Tindakanlah yang menyingkapkan sifat keagenan seseorang sebagai suatu karakter dalam rangkaian naratif sejarah umat manusia. ${ }^{28}$ Tindakan (dan perkataan) bagi Arendt adalah aliran darah yang menyatukan sel-sel individual kita ke dalam seluruh tubuh kemanusiaan di dalam sejarah sebagai sebuah cerita yang utuh. ${ }^{29}$

\footnotetext{
25 Ibid.,179.

26 Ibid., 176.

27 Penulis kira ada pengaruh pandangan Yudaisme mengenai kematian pada pemikiran Arendt ini. Yudaisme memahami kematian sebagai akhir dari partisipasi sosial-historis seseorang. Lihat misalnya Pengkhotbah 9:5-6, “... tetapi orang-orang yang mati tidak tahu apaapa, tak ada upah lagi bagi mereka, bahkan kenangan kepada mereka sudah lenyap. Baik kasih mereka, maupun kebencian dan kecemburuan mereka sudah lama hilang, dan untuk selamalamanya tak ada lagi bahagian mereka dalam segala sesuatu yang terjadi di bawah matahari."

28 Arendt, Human Condition, 182.

29 Ibid.,184-185.
} 


\section{Tindakan dan Munculnya Sang Agen}

Identitas dibentuk di dalam rangkaian narasi yang dilakoni oleh tiap-tiap individu di dalam konteks sosialnya, tetapi hanya dapat 'ditulis' dan 'dibaca' oleh orang-orang di sekitarnya. ${ }^{30}$ menurut Arendt, untuk inilah kota-kota (polis) dalam dunia Yunani kuno dibentuk. The polis was supposed to multiply the occasion to win "immortal fame," that is, to multiply the chances for everybody to distinguish himself, to show in deed and word who he was in his unique distinctness. ${ }^{31}$ Yang dimaksudkan dengan 'kota' di sini bukanlah lokasi geografis dan tembok-temboknya, melainkan organisasi dari para warga kota itu - dengan kata lain, bukan lokasinya, melainkan manusia-manusianya. Di dalam tindakan dan pembicaraan yang terjadi di dalam organisasi warga itulah muncul sebuah kota. Dalam sebuah ungkapan yang menggambarkan bagaimana space of appearance di antara para warga kota lahir di dalam interaksi mereka dikatakan mengenai warga kota Yunani kuno: "Wherever you go, you will be a polis." 32

Orang-orang Yunani kuno membentuk kota-kotanya menjadi ajang perjumpaan antar-manusia demi menggapai keabadian lewat

\footnotetext{
30 Arendt menjelaskan mengenai ini dengan merujuk kepada suatu konsep mengenai daimon di dalam mitologi Yunani kuno (menurut penjelasan Sophocles dalam Oedipus Rex 1186 ff.) Tiap orang memiliki daimon yang mewakili siapakah dirinya yang sesungguhnya - tetapi hanya dapat kelihatan oleh orang-orang lain, tidak oleh dirinya sendiri. "(in the revelatory character of action and speech) ... one discloses one's self without ever either knowing himself or being able to calculate beforehand whom he reveals." Ibid., 192.

31 Ibid., 197.

32 Ibid., 198.
} 
tindakan-tindakan politis yang mereka lakukan dan kata-kata yang mereka ucapkan. Kota-kota itu mengabadikan kisah kehidupan para pahlawannya sehingga identitas, tindakan-tindakan (tindakan) dan kata-kata mereka tidak lenyap ditelan kelupaan ataupun larut di dalam lautan massa tak berwajah ataupun bernama. Dengan kata lain, sebuah kota memberikan kesempatan kepada para penduduknya, melalui keterlibatan politis, untuk memiliki nama, wajah, dan keabadian. Keterlibatan politis melalui kata-kata dan tindakan inilah yang memunculkan Sang Agen sebagai individu yang unik di hadapan wajah-wajah lainnya.

\section{Tindakan, Ruang Penampakan dan Kekuasaan}

Di mana ada orang-orang berkumpul untuk bertukar kata dan tindakan akan muncul ruang penampakan (space of appearance) sebagai dasar dari eksistensi seorang manusia sebagai Agen yang nyata. Ruang ini bersifat sementara, ketika para anggotanya membubarkan diri, ruang itupun akan lenyap. Walaupun dapat dikatakan setiap manusia memiliki kemampuan untuk berkata-kata dan bertindak, tetapi kebanyakan dari kita (seperti di masa lampau budak, orang-orang asing, orang-orang barbar, para pekerja kasar dan tukang, dan di masa kini karyawan atau pebisnis) tidaklah hidup di dalamnya - atau setidak-tidaknya, tidaklah selama-lamanya hidup di dalam ruang itu. ${ }^{33}$ Perkumpulan manusia yang mampu berkata-

\footnotetext{
33 Tentu saja agak aneh untuk kita mendengar Arendt menggolongkan 'karyawan dan pebisnis' sebagai di luar ruang penampakan ini. Bukankah seringkali geliat politik sangat dipengaruhi lobi-lobi dan berbagai 'titipan' dari golongan pebisnis? Bahkan di Indonesia
} 
kata dan melakukan suatu tindakan atau tindakan saja tidaklah cukup untuk menjamin ruang penampakan itu akan atau tetap ada. Kehadiran manusia-manusianya hanyalah memungkinkan hadirnya ruang itu sebagai suatu potensi saja. Yang membuat kumpulan manusia yang berpotensi membuat ruang penampakan itu pada akhirnya benar-benar menghadirkan ruang itu adalah kekuasaan (power). ${ }^{34}$ Ketika kata-kata tidaklah kosong atau menipu dan tindakan tidaklah brutal maka ruang itu akan hadir melalui kata-kata dan tindakan. ${ }^{35}$ Kekuasaan akan diaktualisasikan di dalam ruang antar-individu itu melalui kata-kata dan tindakan dimana ia menjadi suatu 'acted deed' dan 'spoken word' yang bermakna dan berpotensi untuk mengabadikan si Agen. ${ }^{36}$ Kuasa tidak pernah dapat terjadi dalam keterisolasian. Arendt membedakan antara kuasa dan kekuatan (strength). Kekuatan dapat dimiliki setiap individu terlepas dari keterlibatan sosialnya, sedangkan kekuasaan hanya dapat

(misalnya pada periode pemilu 2014) kita melihat fenomena banyak pebisnis yang terjun ke dalam kancah politik, bahkan mencalonkan diri sebagai Presiden ataupun petinggi partai politik? Tetapi penulis kira di sini Arendt tidak sedang membicarakan karyawan ataupun para pebisnis sebagai seseorang, yang dapat melakukan peranan ganda di dalam masyarakat, melainkan sebagai suatu pemeran tunggal tertentu. Dalam pembahasannya mengenai gerakan buruh, Arendt jelas tidak mengecualikan para buruh dari ruang penampakan politis. Ia mengatakan bahwa, "... when the labor movement appeared on the public scene, it was the only organization in which men acted and spoke qua men - and not qua member of society ... the workers today are no longer outside of society; they are its members ..." Ibid., 199 dan 219.

34 Yang dimaksud dengan 'power' di sini merujuk kepada dynamis (Greek) atau potentia (Latin) atau Macht (German). Ibid., 200.

35 Ibid. Power is actualized only where word and deed have not parted company, where words are not empty and deeds not brutal, where words are not used to veil intentions but to disclose realities, and deeds are not used to violate and destroy but to establish relations and create new realities.

36 Ibid., 204-205. 
muncul di dalam tindakan antar-individu itu. ${ }^{37}$

\section{Problema Tindakan dan Solusi-Solusinya}

Menurut Arendt, secara inheren, ada tiga kesulitan dari sebuah tindakan, yaitu: 1) hasilnya tak dapat ditebak, 2) prosesnya tak dapat ditarik lagi, 3) sumber (author) dari tindakan tersebut tak dapat dilacak secara pasti (anonymous). ${ }^{38}$ Arendt membahas dua macam solusi bagi permasalahan ini. Solusi yang pertama adalah apa yang kita temukan di dalam sejarah pemikiran politis Barat sejak Plato dan solusi yang kedua adalah apa yang ia lihat ada di dalam tradisi Judeo-Christian.

\section{Solusi \#1: Mengganti Tindakan dengan Karya}

Selanjutnya Arendt melacak pelarian dari kesulitan yang inheren di dalam sebuah tindakan ini di dalam argumen-argumen melawan demokrasi (dalam hal ini ia mengambil contoh dari Plato) yang mensubstitusi ketidaktertebakan aktivitas bertindak dengan aktivitas berkarya (substitute making for acting). ${ }^{39}$ Bahkan Arendt menuduh Plato sebenarnya hanya sedang menyusun dasar-dasar teori untuk melarikan diri dari dimensi politis manusia - yaitu dengan memisahkan antara 'mengetahui' (knowing) dengan 'melakukan' (doing), antara 'memulai' (archein) dan 'melakukan'

\footnotetext{
37 Ibid.,200.

38 ... unpredictability of its outcome, the irreversibility of its proccess, and the anonymity of its authors ..." Ibid., 220."

39 Ibid., 221-222.
} 
(prattein). ${ }^{40}$ Pemisahan yang kemudian terjadi antara 'mereka yang mengetahui apa yang harus dilakukan tetapi tidak melakukannya' (yaitu: para pemimpin atau tuan) dengan 'mereka yang 'tidak mengetahui apa yang harus dilakukan tetapi hanya melakukan apa yang diperintahkan oleh mereka yang mengetahui apa yang harus dilakukan' (yaitu para terpimpin atau para hamba) mencerminkan pemakaian paradigma keluarga di dalam ranah publik, di mana Plato memandang pengelolaan negara sebagaimana pengelolaan keluarga atau pengelolaan sebuah tubuh. ${ }^{41}$ Dengan kata lain, Arendt berpendapat bahwa Plato dan para pemikir lain yang mengusulkan mon-archy (yaitu kepemimpinan terpusat dimana seluruh negara dipandang dan dikelola sebagai satu tubuh dengan satu kepala) telah melarikan diri dari politik, yaitu aktivitas yang mengaktualisasikan potensi manusia untuk bertindak - atau dengan kata lain dari kebebasan - dengan cara mensubstitusi aktivitas bertindak ini dengan aktivitas berkarya. Si Filsuf-Raja dalam konsep Plato memandang pembangunan kota-negaranya sebagaimana seorang pemahat memandang karya patungnya!42 Substitusi ini jelas berbahaya karena ia merampas kemanusiaan kita dengan menghilangkan dimensi tindakan, yaitu hak untuk memulai sesuatu yang sungguh-sungguh baru dalam hidup manusia di mana dalam hal itulah kita eksis sebagai individu yang unik, demi melarikan diri dari kesulitan-

\footnotetext{
40 Ibid.,223-224.

41 Ibid., 223-225.

42 Ibid.,227.
} 
kesulitan yang dapat terbit dari aktivitas bertindak.

\section{Solusi \#2: Pengampunan dan Perjanjian}

Orang-orang Yunani kuno menjawab permasalahan yang muncul dari niscayanya jerih lelah dengan berkarya. Jerih lelah dari Animal laborans digantinya dengan karya-karya dari Homo faber. ${ }^{43}$ Implementasi dari solusi ini dapat kita lihat di dalam sistem perbudakan yang membebaskan kalangan orang-orang bebas yang mampu membeli budak dari keniscayaan jerih lelah yang tidak meninggalkan jejak apa-apa dari kehidupan mereka. Sistem perbudakan itu sendirilah obyek yang mereka tambahkan ke dalam dunia sebagai karya mereka. Jadi penebusan dari jerih lelah didapati di dalam aktivitas yang lebih tinggi, yaitu berkarya. Tetapi karya itu sendiri, menurut Arendt, menerbitkan permasalahan yang baru. Pemisahan yang dibuat Plato antara 'mengetahui' dan 'bekerja' telah mendevaluasi makna dari kehidupan manusia.

It is indeed true - and Plato, who had taken the key word of his philosophy, the term "idea," from experiences in the realm of fabrication, must have been the first to notice it - that the division between knowing and doing, so alien to the realm of action, whose validity and meaningfulness are destroyed the moment thought and action part company, is an everyday experience in fabrication, whose processes obviously fall into two parts: first, perceiving the image shape (eidos) of the product-to-be, and then organizing the means and starting the execution. ${ }^{44}$

Ketika realitas dibagi menjadi 'sarana' (means) dan 'sasaran' (end),

43 Ibid.,85 dan 144

44 Ibid.,225. 
maka banyak hal dalam hidup kita akan menjelma menjadi sarana belaka. Secara inheren sebuah sarana tidaklah memiliki arti di dalam dirinya sendiri. Makna dari sebuah sarana adalah di dalam kegunaannya (instrumentality) di dalam mencapai sasaran. Arendt berpendapat bahwa pemisahan yang dibuat Plato ini menyebabkan terjadinya praktik 'tujuan menghalalkan segala cara' yang memimpin kepada kekerasan yang tidak terlepaskan dari dunia politik dan sejarah. ${ }^{45}$ Solusi yang ditawarkan Arendt sangat radikal. Ia tidak puas dengan memberikan batasan-batasan pada cara-cara yang masih dapat diterima untuk mencapai suatu tujuan. Menurutnya selama kita memelihara pemisahan antara sarana dan sasaran di dalam alam politik, maka kita tidak akan dapat mencegah siapapun untuk menghalalkan segala cara untuk mencapai tujuannya. Maka Arendt mengusulkan kita untuk meninggalkan substitusi yang berbahaya ini. Ia menyerukan umat manusia untuk tidak mencari solusi bagi permasalahan di dalam aktivitas bertindak dengan melarikan diri ke dalam aktivitas berkarya. Permasalahan-permasalahan dalam tindakan, yaitu ketidaktentuan masa depan dapat dihadapi dengan membuat perjanjian dan menepatinya, sedangkan masalah tak dapat ditariknya ucapan ataupun tindakan (irreversibility) dapat dihadapi dengan kekuatan pengampunan. Dalam kutipan yang sangat terkenal dari bukunya, Arendt mengatakan:

Here, the remedy against the irreversibility and unpredictability of

\footnotetext{
45 Mengutip Karl Marx, "Violence is the midwife of every old society pregnant with a new one." Ibid., 228-9.
} 
the process started by acting does not arise out of another and possibly higher faculty, but is one of the potentialities of action itself. The possible redemption from the predicament of irreversibilty - of being unable to undo what one has done though one did not, and could not, have known what he was doing - is the faculty of forgiving. The remedy for unpredictability, for the chaotic uncertainty of the future, is contained in the faculty to make and keep promises. ${ }^{46}$

Keduanya saling berkaitan dan tidak dapat dilepaskan dari aspek sosial manusia. Orang tidak dapat mengampuni dirinya sendiri, maupun berjanji kepada dirinya sendiri secara nyata. Di hadapan orang-orang lain, dalam ranah sosial, tanpa pengampunan kita akan diikat oleh masa lampau tanpa dapat move on kepada hari-hari yang masih ada. ${ }^{47}$ Sementara tanpa batasan-batasan yang dibuat oleh perjanjian kita dengan orang-orang lain kita akan kehilangan identitas kita. ${ }^{48}$

Arendt melihat kedua solusi ini berkaitan erat dengan asalmuasal dari tindakan itu sendiri, yaitu sebagai sesuatu yang muncul dari faktualitas manusia sebagai mahluk yang plural dan berpotensi memulai sesuatu yang tidak pernah ada sebelumnya. Di dalam mengampuni kita melakukan sesuatu yang sungguh-sungguh baru,

\footnotetext{
46 Ibid., 236-237.

47 Pengampunan ini hanya dapat dikenakan kepada kesalahan-kesalahan yang bukan termasuk ke dalam golongan 'kejahatan radikal' - dimana mengenai hal ini Arendt berpendapat kita tidak dapat mengampuni maupun menghukumnya karena hal itu bersifat transenden mengatasi kekuatan kita sebagai manusia. Ibid., 241.

48 " ... we would be condemned to wander helplessly and without direction in the darkness of each man's lonely heart, caught in its contradictions and equivocalities - a darkness which only the light shed over the public realm through the presence of others, who confirm the identity between the one who promises and the one who fulfils, can dispel." Ibid., 237.
} 
mengatasi karakter otomatis dari siklus kesalahan dan pembalasan dendam (revenge). ${ }^{49}$ Dalam hal ini kita dapat mengatakan bahwa 'kasih itu membebaskan' baik orang yang bersalah maupun orang yang telah menjadi korban kesalahannya itu. Jika kasih terutama efektif di dalam membebaskan kita dari ikatan masa lampau, perjanjian dapat efektif untuk menjadi pegangan kita di dalam menjalani ketidakmenentuan masa depan. Ada harga yang harus dibayar untuk kebebasan dan kesetaraan bagi semua orang di alam demokrasi, yaitu: bagi kebebasan kita membayar dengan ketidakmampuan untuk benar-benar mandiri, sedangkan bagi pluralitas dan egalitarianitas kita harus membayarnya dengan kemustahilan untuk menjadi tuan satu-satunya bagi rancangan dan tindakan kita (karena kita tidak dapat mengetahui konsekuensikonsekuensi apa saja yang akan muncul dari tindakan-tindakan kita).

Dengan demikian, Arendt melihat bahwa dengan kemampuan untuk mengampuni dan menepati janji ketiga predicament dari tindakan (yang muncul dari pluralitas manusia), yaitu: ketidaktentuan masa depan, tidak dapat ditarik kembalinya tindakan dan ucapan, serta ketidakmampuan kita untuk sepenuhnya menjadi tuan atas tindakan dan perkataan kita, justru dapat menjadi sesuatu yang positif. Arendt melihat ketidaktentuan dan pluralitas bukan sebagai ancaman, tetapi sebagai 'jalan penebusan' bagi kelamnya hidup manusia. Dalam paragraf yang gelap secara realistis dan sekaligus menyimpan pengharapan, Arendt menulis:

49 Ibid., 241. 
The life span of man running toward death would inevitably carry everything human to ruin and destruction if it were not for the faculty of interrupting it and beginning something new, a faculty which is inherent in action like an ever-present reminder that men, though they must die, are not born in order to die but in order to begin. ${ }^{50}$

Menurut Arendt, disinilah terletak sumbangsih unik dari Yesus Nazaret dan Yudaisme yang tidak dapat kita temukan di dalam pemikiran Yunani maupun Romawi kuno, yaitu kemampuan untuk memutuskan siklus yang lama dan memulai sesuatu awal yang benar-benar baru, khususnya di dalam kapasitas tindakan untuk melakukan pengampunan dan perjanjian. Iman dan pengharapan itu sendiri dipandang dengan curiga oleh orang-orang Yunani-Romawi kuno sebagai sesuatu yang tidak umum dan bersifat ilusi. ${ }^{51}$ Ia menyebutkan kapasitas untuk bertindak, untuk memulai sesuatu yang baru, interupsi atas apa yang telah ada, sebagai 'penebusan' dari siklus destruktif yang akan menghancurkan umat manusia. Di dalam kapasitas bertindak terkandung 'mujizat' yang disebutnya sebagai 'infinite improbability which occurs regularly'. ${ }^{52}$

\footnotetext{
50 Ibid.,246-7.

51 Ibid., 247.

52 Ibid.
} 


\section{Evaluasi dan Apropriasi}

Pertama, sebagaimana dikatakan oleh Wolterstorff, penulis kira Hannah Arendt benar ketika mengatakan bahwa Yesus dari Nazaretlah yang telah 'menemukan' kekuatan pengampunan di dalam ranah politik, tetapi apakah benar bahwa tidak ada akar dari penemuan ini di dalam ajaran Perjanjian Lama yang dianut bangsa Yahudi di jaman Yesus? ${ }^{53}$ Tentu saja jawabannya adalah negatif. Di dalam banyak tempat kita dapat menemukan bahwa para penulis Perjanjian Lama telah menempatkan pengampunan sebagai suatu kekuatan yang dapat menginterupsi siklus pembalasan dendam. Kita dapat menemukannya pada respon $\mathrm{YHWH}$ atas kesalahan Adam dan Kain. Walaupun mereka menderita konsekuensi dari kesalahan yang mereka perbuat kepada Allah, tetapi Allah tidak 'membalaskan perbuatan mereka secara setimpal'. Adam tetap hidup, kematiannya secara badani ditunda sampai sekian ratus tahun kemudian dan kematiannya secara rohaniah sebagai perpisahan dengan Tuhan tidaklah terjadi secara total. Allah masih berbicara kepadanya, Allah masih memberikan pakaian menutupi ketelanjangannya, dan justru lewat penghukuman yang ditanggung perempuan itu, yaitu melahirkan anak, Allah menjanjikan bahwa suatu hari kelak kepala ular itu akan diremukkan. Kita juga menemukan motif pengampunan pada perlindungan yang Allah berikan kepada Kain agar musuh-musuhnya tidak menemui dan membunuh dia di jalan. Allah bahkan memberkati keturunan Kain sehingga mereka menjadi

53 Nicholas Wolterstorff, Justice in Love (Grand Rapids, Michigan: Eerdmans, 2011), 162. 
bangsa yang memiliki peradaban tinggi. Jelas motif pengampunan kita lihat hadir di dalam narasi Esau dan Yakub. Dalam pergulatannya dengan masa lalu yang buruk, Yakub pada akhirnya diampuni oleh Esau. ${ }^{54}$ Penulis Torah menggambarkan adegan itu hampir-hampir sama dengan cerita yang dipakai Yesus bertahuntahun kemudian untuk menggambarkan Israel yang tidak sudi menerima pengampunan yang Allah berikan kepada 'bangsa-bangsa anjing' yang telah meninggalkan perjanjian dengan diri-Nya (yaitu Samaria). ${ }^{55}$ Yusuf, anak kesayangan Yakub yang pernah dijual oleh kakak-kakaknya ke mesir, ketika akhirnya ia berjumpa kembali dengan kakak-kakaknya itu, ia mengampuni mereka. ${ }^{56}$ Penulis Mazmur 86:5 memuji Tuhan sebagai yang 'baik dan suka mengampuni'. Daud mengalami diampuni oleh $\mathrm{YHWH}$ setelah ia bertobat dari dosanya mengambil istri Uriah dan membunuh suaminya. ${ }^{57}$ Jadi dapat disimpulkan bahwa 'penemuan' kekuatan pengampunan yang kita lihat di dalam ajaran dan praktik hidup Yesus dari Nazaret sesungguhnya berakar di dalam tradisi para penulis Perjanjian Lama.

Kedua, Hannah Arendt menilai pengajaran Yesus Nazaret mengenai pengampunan sangatlah radikal, karena menurut Arendt, Yesus mengajarkan bahwa kitalah manusia yang harus memulai

\footnotetext{
54 Kejadian 33:4.

55 Penulis berbicara mengenai perumpamaan tentang Anak yang Hilang di dalam injil Lukas 15:11-32.

56 Kejadian 45:5 dan 50:15-21.

572 Samuel 12:13 dan Mazmur 51.
} 
pengampunan itu, bukan Allah, bukan juga Allah lewat medium manusia. Manusialah, menurut Arendt, yang menggerakkan proses pengampunan ini, bukan Allah.

It is decisive in our context that Jesus maintains against the "scribes and pharisees" first that it is not true that only God has the power to forgive, and second that this power does not derive from God - as though God, not men, would forgive through the medium of human beings - but on the contrary must be mobilized by men toward each other before they can hope to be forgiven by God also. ${ }^{58}$

Hal yang sama dapat kita lihat juga di dalam perumpamaan Yesus tentang raja yang mengampuni hutang hamba yang tidak mau mengampuni hutang sesamanya yang jauh lebih kecil (Matius 18:2135). Perumpamaan ini adalah jawaban Yesus untuk pertanyaan Petrus, "Sampai berapa kali aku harus mengampuni saudaraku jika ia berbuat dosa terhadap aku?" (Mat. 18:21). Kesimpulan dari perumpamaan Yesus memang mengejutkan: "Maka Bapaku yang di surga akan berbuat demikian juga terhadap kamu, apabila kamu masing-masing tidak mengampuni saudaramu dengan segenap hatimu." (Mat. 18:35). Pembacaan Arendt atas bagian Injil ini terlihat sangat literal. Sebagai orang Kristen yang seringkali mendengar bahwa Injil Yesus Kristus bersifat penuh anugerah dan anugerah pengampunan itu selalu dimulai dari inisiatif Allah, tentu saja

\footnotetext{
58 Arendt, Human Condition, 239. Di sini Arendt mengutip Injil Matius 6:12, 14-15, “Ampunilah kami akan kesalahan kami, seperti kami juga mengampuni yang bersalah kepada kami." dan "... jikalau kamu mengampuni kesalahan orang, Bapamu yang di sorga akan mengampuni kamu juga. Tetapi jikalau kamu tdak mengampuni orang, bapamu juga tidak akan mengampuni kesalahanmu."
} 
penulis merasa terganggu dengan pembacaan yang menantang ini. Tetapi, apakah benar juga bahwa Bapa akan mengampuni orang yang tidak mengampuni saudara-saudaranya sesama manusia dengan sungguh-sungguh? Jika kita memperhatikan bahwa pemirsa yang mendengarkan percakapan Yesus dan Petrus mengenai pengampunan ini adalah murid-murid-Nya yang bertanya pula mengenai: "Siapakah yang terbesar dalam Kerajaan Surga?" (Mat. 18:1) lalu Yesus menjawab dengan memanggil seorang 'anak kecil' ke tengah mereka (Mat. 12:2), lalu menjelaskan tentang betapa berharganya seorang anak kecil sekalipun (Mat. 18:6, 10, 14), maka kita juga dapat lebih mengerti mengapa Yesus menjawab dengan cara seperti ini. Pertanyaan Petrus diletakkan oleh Matius sebagai respon atas ajaran Yesus mengenai "Saudara yang berbuat dosa." (Mat. 18:15). Jadi jika Yesus mengajarkan bahwa di dalam Kerajaan Allah, apa yang dianggap remeh oleh dunia ini (yaitu: anak-anak kecil) punya nilai yang sangat penting di mata Bapa Surgawi, dan bagaimana orang yang berbuat dosa haruslah digembalakan dengan baik untuk pertobatannya (bukan serta-merta diusir dari komunitas atau sekedar dihukum) sebelum ia mengutarakan perumpamaan mengenai pengampunan ini, maka kita memiliki alasan yang cukup kuat untuk menduga bahwa Matius menuliskan perumpamaan tentang anak yang hilang ini untuk menggambarkan praktik komunal umat Tuhan di dalam era datangnya Kerajaan Allah yang harus berbeda dari praktik yang terdapat di antara komunitas yang mengaku sebagai Israel. Diantara karakteristik-karakteristik penting 
yang harus terdapat di dalam umat Tuhan adalah: 1) penghargaan terhadap yang kecil dan lemah (Mat. 18:1, 6, 10) dan 2) perhatian terhadap mereka yang 'terhilang' (Mat. 18:14-15). Kedua karakteristik ini adalah konteks dari ajaran Yesus bahwa seseorang di dalam umat Israel yang baru haruslah siap mengampuni saudara yang berbuat salah, jika ia kembali kepadanya sampai 'tujuh puluh kali tujuh kali.' Dengan kata lain, pengampunan yang diajarkan Yesus di sini harus diletakkan di dalam konteks pemulihan komunitas sesama saudara dan sifat inklusif yang unik dari umat Perjanjian Baru. Penulis kira, Matius di sini tidaklah menjelaskan mengenai siapakah yang memulai proses itu. Tidak seperti Arendt, penulis kira Matius tidaklah mengatakan bahwa Allah tidak akan dapat mengampuni kesalahan kita jika kita tidak memulainya terlebih dahulu. Lebih tepat di sini jika kita katakan, Yesus, sebagaimana dipaparkan Matius, memberikan visi mengenai persaudaraan antar umat Allah di dalam era datangnya Kerajaan Allah, dimana setiap anggotanya begitu berharga di mata Allah, sehingga ikatan persaudaraan itu menuntut setiap anggotanya untuk selalu menyediakan pengampunan bagi setiap anggota lain ketika mereka bersalah kepadanya. Penolakan untuk saling mengampuni adalah juga penolakan terhadap keseluruhan visi Kerajaan yang dikabarkan Yesus ini. Orang-orang Yahudi yang tidak mau percaya kepada berita Injil Yesus memang terhalang oleh karena hal ini: mereka 'iri karena Tuan mereka murah hati' kepada orang-orang yang datang belakangan (yaitu orang-orang bukan Yahudi dan orang-orang yang 
dianggap ${ }^{59}$ tidak layak masuk kerajaan Surga oleh orang-orang Farisi dan para Imam). Jadi dapat kita katakan bahwa walaupun pembacaan Arendt terhadap ajaran dan praktik Yesus untuk saling mengampuni sangatlah insightful dan kreatif, tetapi kita tidak dapat membaca secara literal bahwa Yesus mengajarkan bahwa, "Man in the gospel is not suppose to forgive because God forgives and he must do 'likewise,' but 'if ye from your heart forgive,' God shall do 'likewise.'"60 Penulis dapat mengafirmasi afirmasi Arendt untuk perintah mengampuni dari Yesus, tetapi penulis tidak dapat menerima apa yang menjadi negasinya. Dalam pembacaan Injil Matius secara lebih mendalam, dan juga jika kita mempertimbangkan narasi dan ajaran Kristiani dalam konteks yang lebih menyeluruh, tidak ada penegasan bahwa Allah tidaklah memulai proses pengampunan antar-manusia. Yang kita jumpai di sini justru bahwa ketika 'YHWH kembali ke Sion' di akhir zaman, yaitu pada saat Yesus datang ke dunia ini, Allah telah kembali 'menyayangi umatNya,' seperti yang dinubuatkan oleh nabi Hosea (Hos. 1:10-12; 2:22). Dengan kata lain, seruan Yesus agar umat Perjanjian Baru itu 'saling mengampuni agar Allah mengampuni mereka' haruslah dibaca sebagai sebuah perintah yang telah didahului oleh tindakan Allah membuka pintu ampunan bagi umat-Nya karena nubuatan nabi-nabi Perjanjian Lama mengenai datangnya era yang baru itu akhirnya

\footnotetext{
59 Matius mencatat perumpamaan Yesus tentang para pekerja upahan di kebun anggur di mana Ia mengakhirinya dengan kalimat penutup: "Demikianlah orang yang terakhir akan menjadi yang terdahulu dan yang terdahulu akan menjadi yang terakhir." (Mat. 20:1-16).

60 Arendt, Human Condition, 239.
} 
telah tiba bagi Israel. Tindakan murid-murid Yesus untuk menghidupi pengampunan Allah di dalam saling mengampuni yang mereka praktikkan satu sama lain itu adalah langkah ketaatan mereka untuk dapat masuk di dalam keseluruhan pengampunan yang telah Allah sediakan itu. Dengan demikian tindakan pengampunan Allah tidaklah digerakkan oleh tindakan pengampunan kita, melainkan tindakan orang-orang Kristen untuk saling mengampuni adalah diinisiasi oleh tindakan Allah yang, di dalam kutipan Arendt sendiri, telah memberikan "Seorang Putra bagi kita."

Ketiga, analisa Arendt mengenai substitusi tindakan dengan aktivitas berkarya, yang terjadi di dalam sejarah politik Barat, dalam pengamatan penulis, terjadi pula di Republik kita. Beberapa ciri yang dapat kita lihat, diantaranya adalah: Pertama, sikap instrumentalis dalam mendekati hampir segala persoalan politik. Ini nyata dalam sikap transaksional baik dalam masa pemilihan umum legislatif, pilpres, maupun penyusunan kabinet. Penulis kira peringatan Arendt mengenai 'sasaran baik yang pada akhirnya menghalalkan segala cara secara tidak terhindarkan' harus dicermati. Selama kita masih memakai metafora 'membuat' di dalam tindakan-tindakan politis maka represi terhadap pluralitas suara-suara yang lain akan tetap terjadi. Hanya ada satu suara untuk Sang Filsuf-Raja di dalam sebuah 'monarki' di mana orang-orang yang lain akan terisolir satu sama lain dan mengalami dominasi. Seperti dalam proses fabrikasi, bahan baku haruslah menurut sepenuhnya kepada rancangan dari si tukang, 
demikian tidak ada ruang kebebasan di dalam atmosfer politik instrumentalistis dimana pemisahan antara 'mereka yang mengetahui' dan 'mereka yang melakukan' terjadi dengan begitu mendalam. Dalam keadaan seperti ini kita tidak akan dapat mencegah orang untuk menghalalkan segala cara' untuk mencapai tujuan-tujuannya. Kedua, tiadanya niat baik untuk rekonsiliasi (pengampunan). Salah satu syarat mutlak untuk rekonsiliasi adalah adanya pengakuan bahwa kejahatan telah terjadi. Tetapi di dalam sikap mengubur masa lampau yang tercermin di dalam keengganan para penguasa untuk dengan serius menyingkapkan fakta-fakta di dalam tragedi pembantaian 1965-66, peristiwa Mei 1998, penculikan aktivis reformasi, pembunuhan Munir, dan lain-lain, mengakibatkan tidak mungkinnya terjadi rekonsiliasi. ${ }^{61}$ Di dalam analisa Arendt hal ini akan berujung kepada stagnasi sejarah dimana kita semua sebagai bangsa akan terjebak kepada satu (atau beberapa) momen kelam di dalam sejarah yang kita coba 'lupakan' itu. Usaha melupakan sisi kelam sejarah tidak menolong kita sebagai bangsa di masa depan karena ketidakadilan yang dirasakan si korban (yang dalam beberapa kasus di atas diduga berjumlah ribuan bahkan ratusan ribu jiwa) akan terus menghantui dan mengikat masa depan sosialnya. Pengampunan juga tidak dapat diberikan kepada si pelanggar yang

61 Dina Sasti Damayanti di dalam "48 tahun G30S, Menolak Lupa" (Harian Sinar Harapan, 28 September 2013) menulis: “Ia (Putu Oka) mengatakan, para pelaku Tragedi 30 September yang menculik dan membunuh para jenderal sudah diadili dan dieksekusi, tetapi mereka yang membunuh 3 juta rakyat, seperti diakui komandan pasukan khusus tentara RPKAD Jenderal Sarwo Edhie Wibowo, justru dibiarkan." 
tidak mengakui kesalahannya, tidak mengetahui kesalahannya, ataupun tidak bertobat dari kesalahannya. Pengampunan itu juga tidak dapat diberikan sepihak dari orang yang menderita ketidakadilan itu. Dalam pembahasannya mengenai syarat-syarat bagi pengampunan, Wolterstorff menyatakan pentingnya pertobatan dari pihak yang telah berbuat kesalahan:

Finding it impossible to forgive, one may try to escape the wrongdoer's psychological control by getting to the point where the deed is for one a mere bygone. But letting the deed become, or getting it to become, a mere bygone, though it extricate one from the wrongdoer's psychological control, does not extricate one from the fact that one has been wronged and that the wrongdoer continues to stand behind what he did. The unrepentant wrongdoer continues to have that sort of moral control over his victim. The victim may put the deed out of mind; but that does not alter the moral fact that she has been wronged by someone who has no regrets. ${ }^{62}$

Terjadinya substitusi dari tindakan kepada karya, sebagaimana telah penulis paparkan di atas, membuat analisa Arendt relevan di dalam kehidupan politis di Indonesia. Mungkin inilah penyebab dari terlalu sempitnya 'ruang penampakan' dari pluralitas subyek-subyek di dalam ruang publik kita. Ranah publik kita, seperti juga lapanganlapangan dan jalan-jalan raya kita, mungkin terlalu disesaki oleh beragam kepentingan yang melihat polis kita hanya sebagai sarana untuk membangun suatu karya yang akan mengabadikan kehidupan siapapun yang dapat menguasainya. Setiap kita berlomba-lomba untuk menjadi pemain sepak bola yang menyarangkan gol ke

62 Wolterstorff, Justice in Love, 175. 
gawang lawan. Bagaimanakah solusi yang ditawarkan Arendt dapat menolong? Secara praktis mungkin kita dapat memulai untuk belajar saling percaya dan menjadi orang-orang yang dapat dipercaya di dalam perjanjian. Kita sebagai bangsa harus mulai untuk belajar mempercayakan diri kepada orang lain, dan belajar pula untuk tidak mengkhianati kepercayaan yang telah diberikan. Dengan kata lain, belajar menghidupi covenant. Dan ketika kepercayaan itu dikhianati, kita harus belajar untuk saling mengampuni. Dalam hal ini penulis kira orang-orang Kristen memiliki banyak sumber yang melimpah untuk menjadi inspirasi bagi bangsa ini. Terakhir, sebagaimana menurut Margaret Canovan, pesan paling menonjol di dalam The Human Condition adalah di dalam konsep natalitas manusia dan potensinya untuk memulai sesuatu yang baru. Dapat dikatakan, dalam pandangan Arendt, keselamatan bagi umat manusia akan datang melalui 'kelahiran' dan bukan 'kematian' (sebagaimana ditekankan oleh mentornya, Martin Heidegger). ${ }^{63}$ Kekuatan natalitas manusia untuk memulai sesuatu yang tidak pernah terpikirkan ataupun muncul sebelumnya untuk memecahkan kebuntuankebuntuan yang dialami umat manusia (atau dalam istilah Arendt: sebuah kekuatan mujizat dari manusia) telah kita lihat di tahun 1989 ketika kekuatan yang tak terprediksi sebelumnya telah merobohkan tembok Berlin tanpa kekerasan berdarah. Tidak ada yang menyangka rangkaian peristiwa itu akan begitu cepat memimpin kepada akhir dari masa perang dingin. Demikian di Indonesia kita menyaksikan

63 Arendt, Human Condition, xvii. 
juga sebuah Arendtian event di dalam 'fenomena Jokowi dan Ahok' dimana orang-orang itu muncul 'out of nowhere' menjadi suatu terobosan yang tak diperhitungkan oleh siapapun dan menjadi suatu gelombang tak terbendung untuk memutar-balikkan banyak tatanan yang telah mapan. Inilah kekuatan power yang muncul dari sebuah tindakan bebas, yang seperti dikatakan Arendt, berbeda dari strength dan force yang muncul di dalam paradigma making yang diterapkan di dalam kehidupan politis. Jika kita berinvestasi kepada force dan strength, yang memang tidak perlu merepoti diri dengan resiko dari pluralitas asalkan kita punya cukup kekuatan untuk mengendalikan, maka kita akan hanya mengandalkan apa yang telah kita miliki, kuasai dan buat, sedangkan power membutuhkan keterbukaan kepada suara-suara yang plural, dan sebagai akibatnya, menyiapkan kita juga kepada beragam kejutan yang berpotensi terjadi oleh dilepaskannya suara-suara terpendam itu. Arendtian events, terjadi secara tidak terduga-duga, suatu mujizat dalam sejarah sekuler, bukan karena kekuatan militer, uang, ataupun lobby - tetapi sebagai hasil dari peristiwa spontan yang satu menyusul yang lain dimana tidak seorangpun dapat memprediksi dampaknya dari semula dan merunut siapakah 'dalang'nya yang tiada kelihatan itu. Tetapi kita yang percaya kepada Bapa dari Tuhan kita Yesus dari Nazaret tahu, Dia yang mendengar doa orang-orang tertindas, Dia yang pernah melepaskan umat-Nya dari perbudakan Mesir, Dia yang tahu bagaimana membangkitkan Orang Benar-Nya dari kematian, adalah Allah yang sama yang berdaulat atas sejarah dunia ini. Kita manusia, 
hanyalah mortals belaka, tidak seorangpun yang dapat memastikan gerak sejarah, seperti dikatakan Arendt mengenai predicament dari tindakan. maka respon yang tepat bukanlah memastikan tingkat kendali kita atas peristiwa-peristiwa, melainkan kesetiaan dalam memegang perjanjian dan kesediaan untuk mengampuni orang yang bersalah kepada kita ketika mereka menunjukkan pertobatannya.

TUHAN menegakkan kembali orang-orang yang tertindas, tetapi merendahkan orang-orang fasik sampai ke bumi. Bernyanyilah bagi TUHAN dengan nyanyian syukur, bermazmurlah bagi Allah kita dengan kecapi! Dia, yang menutupi langit dengan awan-awan, yang menyediakan hujan bagi bumi, yang membuat gunung-gunung menumbuhkan rumput. Dia, yang memberi makanan kepada hewan, kepada anak-anak burung gagak, yang memanggil-manggil. Ia tidak suka kepada kegagahan kuda, Ia tidak senang kepada kaki laki-laki; TUHAN senang kepada orang-orang yang takut akan Dia, kepada orang-orang yang berharap akan kasih setia-Nya. ${ }^{64}$

\section{Kesimpulan}

Hannah Arendt menilai telah terjadi pengabaian sistematis sepanjang sejarah terhadap potensi manusia yang paling melekat dengan keberadaan uniknya sebagai pribadi, yaitu untuk melakukan tindakan. Dikotomi antara berpikir dan bertindak, memulai dan menjalani, yang inheren di dalam filsafat politik Plato, telah mensubstitusi potensi bertindak ini dengan berkarya. Substitusi ini telah merampas kesempatan tiap individu untuk menyuarakan eksistensinya yang unik dan juga akan membatasi kekuatan sebuah masyarakat untuk memecahkan banyak kebuntuan-kebuntuan.

64 Alkitab LAI, TB 1974, Mazmur 147: 6-11. 
Substitusi ini dikondisikan untuk menghindari tiga predicament dari tindakan, yakni: ketidaktentuan dampaknya, ketidakmungkinan sebuah tindakan untuk ditarik lagi, dan ketidakmampuan untuk memastikan peran subyek untuk sebuah tindakan. Arendt mengusulkan solusi alternatif untuk ketiga predicament itu yakni melalui kesiapan untuk mengampuni kesalahan-kesalahan orang ketika mereka berbalik dari kesalahan-kesalahannya itu dan juga untuk membuat serta menepati janji. Kedua solusi itu dapat ditemukan akar-akarnya pada tradisi Judeo-Christian. Arendt memaparkan keunggulan solusinya yang terakhir dan kelemahan dari substitusi tindakan dengan karya. 